important post, acquired the affection and esteem of the service to an extent unparalleled, he was selected to succeed the late lamented Sir John Barrow, Bart., in the second Secretaryship of the Admiralty". 1

9. Sir John Richardson was born in 1787 and studied medicine at the University of Edinburgh. In April 1807 he entered the Royal Navy as surgeon, and after wide service in the wars against France and the United States he returned to study medicine, natural philosophy and natural history at Edinburgh. From 1819 to 1822 , and again from 1825 to 1827 , he was surgeon and naturalist with Franklin's two overland expeditions to the shores of the Arctic Ocean. On the latter occasion he commanded the two boats which surveyed the coast between Mackenzie River and Coppermine River. In 1838 he was promoted to the rank of Physician to the Fleet, and in 1840 became Inspector of Hospitals and Fleets. In 1850 he was sent in command of a Franklin Search expedition overland to the north coast of America.

10. Captain Frederick Wildiam Beechey entered the Royal Navy at the age of ten and served in the wars against France and the United States. In 1818 he was appointed to the Trent brig, commanded by Franklin, and took part in Buchan's expedition to Spitsbergen. In the following year he accompanied Parry's first arctic expedition. In 1821-22 he was engaged on a land survey of the northern coast of Africa from Tripoli eastwards. In 1825 he was appointed to command the Blossom and sent round Cape Horn to Bering Strait, there to act in conjunction with the contemporaneous expeditions of Franklin and Parry in search of a North-West Passage. In August 18:26 the Blossom's barge, under Thomas Elson, master, reached Point Barrow in lat. $71^{\circ} 23^{\prime} \mathrm{N}$., long. $156^{\circ} 21^{\prime} \mathrm{W}$., only 146 miles from the farthest point reachcd by Franklin when exploring westwards from the Mackenzie River delta in 1826. The Blossom finally returned to Spithead in 1828, having completed a voyage of 73,000 miles. Beechey later went to South America with the Sulphur survey vessel and from 1837 was employed in surveying the Irish coasts.

\title{
ICE WORMS
}

Attention has recently been directed to the occurrence of these Oligochaetcs by a letter from N. E. Odell to Nature ${ }^{5 *}$ and by notices in the press. Odell reports that he found a considerable number on Seward Glacier in August 1949, during Project "Snow Cornice". See the Polar Record, Vol. 6, No. 41, 1951, p. 97-99.)

In $1930 \mathrm{~J}$. Stephenson ${ }^{10}$ summarized the information available up to that date, quoting, inter alia, the authors mentioned by Odell (P. S. Welch ${ }^{12}$; I. C. Russell ${ }^{7}$; C. Emery ${ }^{1}$ ). Most of the records undoubtedly come from North America and most of the specimens are referred to the species Mesenchytraeus solifugus. These accounts, however, differ from that of Odell since (as its specific name implies) this species is considered to be negatively phototactic, appearing on the surface of the snow in the late afternoon and retreating

1 Idem. p. 27.

* For references see p. 391. 
below the surface soon after dawn. Odell's suggestion that the worms might be migrating from one glacier lake to another is interesting and might be connected with their daylight activities.

The records of the occurrence of Oligochaetes in ice are sufficiently numerous for the fact that they do so occur to be accepted; but their occurrence in this situation raises some interesting physiological problems. It is axiomatic that invertebrates can and do adapt themselves to the temperature of their surroundings and can survive a fairly wide range of temperature fluctuation. C. G. Rogers and E. M. Lewis, ${ }^{6}$ in laboratory experiments conducted on Lumbricus terrestris, showed that this Oligochaete rapidly adjusted its temperature to that of the surrounding medium (in this instance the worms were immersed in water). Records are also available which show that completely frozen Oligochaetes will survive. J. P. Moore describes how specimens of Limnodrilus exposed during cold nights in a tumbler of water were frozen solid, but most were still alive at the end of the winter. (See also J. Stephenson $^{9}$ and W. Michaelsen ${ }^{3}$ for Enchytraeus.) It is reasonable to suppose that this capability varies with different Oligochaetes, even of the same habitat, also as between aquatic and terrestrial forms. It is known that Lumbricids have survived temperatures ranging from $-2^{\circ}$ to $-5^{\circ} \mathrm{C} .\left(+28^{\circ}\right.$ to $+23^{\circ} \mathrm{F}$.), but from $-4^{\circ}$ to $-8^{\circ} \mathrm{C} .\left(+25^{\circ}\right.$ to $+18^{\circ} \mathrm{F}$.) many did not recover and those that did died shortly afterwards. Some Tubifex tubifex, however, recovered after exposure to such temperatures for 10 hours.

The evidence, therefore, is in favour of Oligochaetes being able to exist in water at low temperatures, but it must not be forgotten that although the water may have frozen, the worms themselves, by virtue of the heat rcsulting from their respiratory processes, may maintain a temperature above that of the surrounding ice. This may be conducive to their survival in these conditions.

Of the food of worms in these situations, little seems to be known. E. W. Gudger ${ }^{2}$ advances the view that Enchytracids found in snow at 5000 feet in Oregon lived on the algae abundant in it. Some organic material will be essential for the continued existence of these worms and it is interesting that Odell's record states that there was no silt in the pools where his specimens abounded. It would be interesting to know more about the organic matter (in such form as plant spores or cysts of Protozoa) found on glacier surfaces, for it would seem that worms like Mesenchytraeus solifugus come up on the surface to feed, to copulate or to migrate. According to G. Seligman, ${ }^{8}$ glaciers are covered with a coating of dust blown, in the summer, from surrounding hills. V. Vareschi ${ }^{11}$ cites instances in which pollen and plant particles were found in glacier ice. Where silt or other earthy material is present at reasonable distance beneath the glacier it is not impossible that worms could make use of it, for P. S. Welch ${ }^{12}$ showed that $M$. gelidus could burrow into ice or snow.

A further point upon which there seems to be no information is the reproductive activities of these worms. When and where do they breed, what is the form of the cocoon, and where is it deposited?

It would appear, therefore, that ice worms are examples of invertebrates 
which have adapted their metabolic activities to life at low temperatures and should, if material is made available, provide an interesting field for research.

\section{References}

A. J. GROVE

1 Emery, Carlo. On Melanenchytraeus solifugus, in F. DE FiLipPi, The ascent of Mount St Elias. London, Constable, 1900, p. 224-28.

3 Gudgen, E. W. Snow worms. Enchytraid worms found in the snow and on the glaciers of high mountains. Natural History, Vol. 23, No. 5, 1923, p. 450-56.

${ }^{3}$ Michaelsen, W. [no title], in Die Tierzell der Nord-und Ostsee. (Leipzig), Lieferung 9, Teil $6 c, 1927$.

- Moore, J. P. A snow-inhabiting Enchytræid (Mesenchytraeus solifugus Emery) collected by Mr Henry G. Brant on the Malaspina Glacier, Alaska. Proceedings of the Academy of Natural Sciences of Philadelphia, 1899, Part 1, p. 125-44.

3 Odeln, N. E. Ice-worms in Yukon and Alaska. Nature, Vol. 104, No. 4182, 1949, p. 1098.

- Rogers, Cimarles G. and Lewis, Elsie M. The temperature coefficient of the rate of contraction of the dorsal blood-vessel of the earthworm. Biological Bulletin, Vol. 27, No. 5, 1014, p. 269-74.

- Russell, Israel Cook. Second expedition to Mount St Elias. Thitteenth Annual Report of the United States Geological Survey to the Secretary of the Interior, 1891-92... (pub. 189:3), Part 2, p. 7-91.

8 Seligman, G. Private communication [1051].

- Strepilenson, .J. The Oligochacta of the Oxford University Spitsbergen Expedition. Proceedings of the General Meetings for Scientific Business of the Zoological Society of London, 1022, p. 1109-38.

20 Stlimenson, J. The Oligochaeta. Oxford, 1930.

"VARliscin, V. Die pollenanalytische Untersuchung der Gletscherbewegung.... Verüffentlichungen des Geobotanischen Institutes Rübel in Zürich, 19. Heft, 1942.

1.2 IVLLcI, P. S. Transactions of the ilmerican Microscopical Society, Vol. 35, 1016, p. 85-124.

\section{THE PHYSIOLOGY OF SKI-ING}

[Review of "Physiology of skiing", by Hohwï Christensen and P. Högberg, Alrbeitsphysiologie, Bd. 14, 1950, p. 202-303.]

This paper gives the results of physiological observations on a number of skilled and well-trained skiers, made either on level terrain, or going uphill. It is now clear that it is possible when ski-ing to take harder physical exercise (as judged by the amount of oxygen consumed) than in any other way, except, perhaps, when running. Ski-ing makes use of practically every muscle in the body and a high output of energy can be muintained for long periods. In one case $30 \mathrm{~km}$. of level terrain was covered in $1 \mathrm{hr} .20 \mathrm{~min}$, this being well above the world's record for running the same distance.

A man ski-ing for 6 hours at $6 \mathrm{~km}$.p.h., carrying a $30 \mathrm{~kg}$. rucksack, may expend $4900 \mathrm{~kg}$. cal. of energy. Christensen and Högberg suggest that a ski-er carrying such a load may need a daily intake of up to $7000 \mathrm{~kg}$. cal., which is well above what is normally considered necessary when preparing a ration scale for an expedition. Certainly no similar data have been available in the past for expeditions planning to use skis.

A comparison is made of the energy expended in covering a given distance at fixed speed. Compared with walking on soft snow, snowshoes give an energy saving of $20 \%$ and a further $15 \%$ is saved by skis. Even in climbing 